\title{
Bilingual Education, Indigenous Language and Culture: The Case of Apyãwa Tapirapé
}

Educação bilíngue, língua e cultura indígenas: o caso dos Apyãwa Tapirapé

Maria Gorete Neto*

Universidade Federal de Minas Gerais

Belo Horizonte Minas Gerais / Brasil

ABSTRACT: Bilingual schools are recognized as an important resource to increase the chances of language survival but in many cases have proven to be ineffective. Within the Apyãwa Tapirapé Indian Tribe (central Brazil), an effective bilingual school does exist; however, this study shows that even a successful school brings complications for the community. Audio-recorded interviews, in which teachers and leaders discuss their bilingual school and its consequences for the Apyãwa Tapirapé people, reveal that they feel that the school has changed the Apyãwa Tapirapé lifestyle in both negative and positive ways. A continuous evaluation and ongoing reconstruction of educational aspects is proposed as a way to both attend to the needs and to relieve the worries of groups like the Apyãwa Tapirapé with respect to the impact of their school on the community.

KEYWORDS: Apyãwa Tapirapé, bilingual school, indigenous language, indigenous culture, Portuguese.

RESUMO: As escolas bilíngues são consideradas um importante instrumento no propósito de promover línguas ameaçadas, mas, em muitos casos, elas não têm obtido sucesso. Entre os Apyãwa Tapirapé (Brasil Central), existe uma escola bilíngue de sucesso. Mesmo assim, como este estudo aponta, a escola traz complexidades para o povo em questão. Em entrevistas nas quais professores e lideranças discutem sobre sua escola e suas consequências para o povo Apyãwa Tapirapé, temos a percepção de que a escola tem mudado o modo de vida do seu povo, em aspectos tanto positivos como negativos. Uma avaliação e uma reconstrução contínua da escola são indicadas como um caminho para atender às necessidades e aliviar a preocupação de povos como o Apyãwa Tapirapé em relação ao impacto que a escola pode trazer para essas comunidades.

PALAVRAS-CHAVE: Apyãwa Tapirapé, escola bilíngue, língua indígena, cultura indígena, língua portuguesa.

* marigorete_neto@yahoo.com.br 


\section{Introduction}

Numerous studies indicate that many indigenous languages around the world are headed for extinction and will disappear within the next century (KRAUSS, 1992; HALE, 1992; NETTLE \& ROMAINE, 2000). To preserve and revive these languages, both indigenous people and researchers (e.g. KRAUSS, 1992, HINTON, 2001) acknowledge that bilingual schools are an important resource for increasing the chances of language survival. However, many such "bilingual" schools have been ineffective due to the pressure imposed by dominant languages, which causes many of these schools to neglect the indigenous languages. Nevertheless, there are some bilingual schools that have been teaching both indigenous and dominant languages effectively - the school of the Apyãwa Tapirapé Indian Tribe (central Brazil) is a case in point.

The Apyãwa Tapirapé bilingual school can be considered a successful example of an indigenous school for several reasons. Its curriculum takes into account the indigenous culture, all teachers are natives, the primary language of instruction is Tapirapé, and it includes a strong program of teaching Portuguese as a second language, which also develops the indigenous students' ability to communicate satisfactorily in the dominant non-indigenous language. Despite the effective bilingual instruction, however, Apyãwa Tapirapé teachers and leaders have argued that the school has changed the Apyãwa Tapirapé lifestyle in both negative and positive ways.

This study addresses the effects of bilingual schooling on the Apyãwa Tapirapé language and culture. To understand the point of view of that community, the following research question was formulated: "Which Apyãwa Tapirapé representations have been constructed about: a) Tapirapé and Portuguese languages spoken in the village? b) in the school?" Following ethnographic perspectives (ERICKSON, 1984, 1989; CAVALCANTI, 2000; MASON, 1997; EMERSON et al., 1995; ELY et al., 1991), the main kind of data used were audio-recorded interviews conducted with Apyãwa Tapirapé teachers and leaders. They discussed their bilingual school and its consequences for their people. The study demonstrates that even an effective bilingual school may introduce considerable complexities for an indigenous community, which may have a direct impact on cultural and linguistic maintenance. While no simple solutions are at hand, we propose a continuous evaluation and ongoing reconstruction of educational aspects, directed by the community, as an essential part of assessing and reducing these concerns. 


\section{Endangered languages and bilingual schools as a resource for increasing the chances of language survival}

An ongoing discussion about endangered languages and strategies for their revival and maintenance has been taking place in recent years, particularly in the field of linguistics. Various ways to preserve and maintain those endangered languages have been suggested. This work focuses on one of these-educational programs. Krauss (1992) suggests that, for languages that are still learned by children, a significant part of the maintenance effort should be undertaken in school. Educational programs make an important contribution to reestablishing pride in the indigenous language and culture by including components of the native language and culture in their curriculum. Working educationally, culturally, and politically increases the chances of the survival of these languages, which means it is important to involve both the communities as well as researchers and the government in this work in order to produce pedagogical materials and literature to promote the use of these languages. It is also necessary that governments support language planning in these communities and create conditions to encourage the use of these languages. Similarly, Hinton (2001) argues that there are different steps that can promote language revitalization, depending on the kind of language loss, and most of those steps involve educational programs. In some cases, it is necessary to develop new pedagogical programs, such as constructing a bilingual program directed toward second language learning for adults as well as developing intensive courses for children, with components in the school, using the endangered language as the language of instruction. Hinton identifies three types of school-based programs for language revitalization, which vary in goals, limitations, and results: (1) the fullscale immersion program, (2) teaching an endangered language as a second language, and (3) the bilingual education program. The third (which is also the focus of this paper) can, as the author points out, help to shape new domains of use for the endangered language, since its use as an instructional language can result in true balanced bilingualism. However, one disadvantage is that bilingual education depends on good funding and governmental support to maintain schools and to train teachers. Successful examples of school-based programs include the endangered second language program in public schools in Humboldt County, California, where Tolowa, Hupa, Karuk, and Yoruk are taught as second languages, and the immersion programs that have resulted in an entire generation of new speakers of Maori and Hawaiian languages (HINTON, 2001). 
Despite these examples of successful educational programs, many others have failed in their goals. In Julca-Guerrero's (2000) study of bilingual schools in Peruvian Quechua communities, the author observes that effective bilingual teaching does not occur due to an asymmetric relationship between Quechua language and Spanish, since the indigenous language is not taught effectively. Many factors contribute to this failure. First, pressured by international politics, the Peruvian government has simply imposed the bilingual school on indigenous people without engaging in a discussion with the communities involved in the process. These schools do not take into account the indigenous culture and in many cases have simply been a means for the government to obtain funds from international agencies. Furthermore, politicians do not tend to promote the use of indigenous languages, so financial investments in bilingual schools are often not made. One consequence of this situation is that Quechua teachers are not prepared to teach in the native language, since many do not have confidence in the idea of bilingual education and most lack training. There is also little written material in which Quechua instruction can be carried out, teachers are not trained or encouraged to create these materials, and no funds are available to pay professionals to do so. Moreover, instruction in Quechua is restricted to two hours a week or less, so that Spanish assumes the position of the instructional language, thus enforcing the asymmetry between Spanish and Quechua. Finally, inside the Quechua communities there is a common belief, encouraged by the majority society, that Spanish is a better language and that it enables economic ascension. All these factors reported by Julca-Guerrero contribute to unsuccessful bilingual schools, since these schools do not promote the minority language.

Such problems are not restricted to bilingual schools in Peruvian Quechua communities. According to Hilaria Cruz (2008, personal communication), Chatino communities from Southern Mexico present problems that are similar to those experienced in Peru: a lack of governmental support, low community confidence that their language is suitable for the school, and professionals who are unprepared to teach or to prepare materials in the indigenous language. Similarly, in the United States, Watahomigie and Yamamoto's (1992) description of the Hualapai Bilingual/Bicultural Education Program of Peach Springs, Arizona shows that while a successful bilingual program may ultimately be possible, reaching its goal is a slow and burdensome process. At the beginning of the Hualapai program, for example, the language of instruction in schools was English, and all students left school 
speaking English but not Hualapai. There was the idea that indigenous languages were not complex languages and could not be taught in school. The researchers and the community leaders, interested in promoting Hualapai, had to fight against this point of view, and now, after decades of work, the Hualapai community has an effective bilingual school, which encourages and promotes the use of both the indigenous and the non-indigenous language. All of these testimonies indicate that it is not so easy to construct a successful educational program for minority languages.

In Brazil, bilingual education programs share some similarities with the programs cited above. Many were originally imposed by missionaries (Catholic or Protestant SIL), e.g., the Xavante, Bororo ${ }_{2}$ and Karaja schools (central Brazil) and the Kaingang schools (southern Brazil), to cite a few (Silva, 1998; D'Angelis, 2003). The main goal of these schools was to convert indigenous children to Christianity and/or to foster the translation and reading of the Bible in the indigenous language. In some cases, indigenous children were separated from their parents and admitted to a mission school to receive both schooling and Christian doctrine. The indigenous language was used only as a language of transition to Portuguese. In addition, the model for the indigenous schools was drawn directly from non-indigenous Brazilian schools, thus the indigenous culture and social patterns were not taken into account. Since these schools were not in fact constructed to attend to the needs of the indigenous communities, even today the students tend to leave these schools with no skills in reading and writing in either the indigenous language or Portuguese. Currently, although there are still many missionaries trying to persuade indigenous people to abandon their religion and culture and convert to Christianity, the most culturally insensitive mission schools have become largely extinct, and many indigenous peoples have undertaken efforts to construct schools that work effectively for them. In this process of construction, however, there are many obstacles and problems similar to those discussed above. Supported by Brazilian laws (particularly the Constitution of Brazil, 1988) that recognize indigenous peoples' right to speak their languages and express their cultures, there is an effort to reshape these schools to be both compatible with the indigenous culture and to help indigenous people deal with the non-indigenous world. However, despite modern Brazilian law, the Brazilian Government has failed to financially support the indigenous schools or to construct linguistic policies that promote indigenous rights. 
Although many Brazilian indigenous communities have experienced these problems in constructing and maintaining viable schools, there are some indigenous communities that have been more successful. Some of the best examples are the Tuyuka school (northwest Brazil) and the Myky and Apyãwa Tapirapé schools (central Brazil). These schools have adopted a bilingual/ bicultural curriculum, and their educational programs are structured according to the linguistic and cultural needs of the communities. Subjects such as native agricultural practices and traditional handicrafts are part of a curriculum in which the indigenous language is the language of instruction, and Portuguese is taught as the second language. In this paper, we focus on one of these communities - the Apyãwa Tapirapé.

\section{The Apyãwa Tapirapé people and their bilingual school}

The Apyãwa Tapirapé people live in Mato Grosso, central Brazil. They are about 800 individuals in number who live in several small villages in two protected areas or reservations (Urubu Branco and Tapirapé-Karaja). They speak Tapirapé (from the Tupi-guarani family) as their mother tongue.

The history of the Apyãwa Tapirapé school begins with the Apyãwa Tapirapés fight for their traditional lands. In the late 1960s, the Apyãwa Tapirapé lands were being invaded and deforested by non-indigenous people. To prove that they were owners of the indigenous land, the invaders produced maps and documents written in Portuguese. Until that time, the Apyãwa Tapirapé had not been interested in having a school. After the invasion, however, they felt that the school could be useful for them in that it could help them understand the Portuguese language and the maps used by the invaders. They directed their request for a school to some Catholic missionaries - the "Little Sisters of Jesus" - who had been living with them since 1952. These missionaries sent the Apyãwa Tapirapé request on to a secular couple, both teachers. This couple then came to live in the village to help the Apyãwa Tapirapé found a school and to construct a curriculum for them. This curriculum was based on the "Paulo Freire pedagogy", an approach to schooling founded by Freire $(1967,1968)$ which stresses compatibility with the local culture. At first, only adults attended classes, with the goal of preparing Apyãwa Tapirapé leaders to deal with the invaders as quickly as possible. Currently, however, the school includes both elementary and high school levels. The language of instruction is Tapirapé, all teachers are Apyãwa Tapirapé, and there are specific schedules for classes in Tapirapé and in Portuguese as a 
second language. Students leave school competent in the reading and writing of both Tapirapé and Portuguese (DIAS DE PAULA, 2000). Since 2006, roughly half of the Apyãwa Tapirapé students who have applied to attend Brazilian universities have been accepted after passing Portuguese proficiency exams.

If we compare the Apyãwa Tapirapé school with other less successful indigenous schools in Brazil, we can identify specific factors that contribute to its success. First, the school was originally requested by the Apyãwa Tapirapé people, rather than being set up by non-governmental organizations or imposed by missionaries, as was the case with the Xavante school and others cited above. The Apyãwa Tapirapé school is therefore not associated with the cultural violence of missionaries. Although its founding was related to the struggle over land, we can assume that school has a political and symbolic significance for the Apyãwa Tapirapé, since the fight for traditional lands has meant the fight for that people's survival. Second, the respectful attitudes of the school's non-Apyãwa Tapirapé founders have been an essential part of its development. These founders worked with the Apyãwa Tapirapé rather than for them; they listened to the views and wishes of the community; and they respected the indigenous sense of time - requiring long deliberation for all decisions - and the choices made by the Apyãwa Tapirapé, even when these decisions were contrary to the founders' own points of view. Even nowadays, each decision regarding the school is discussed by the Apyãwa Tapirapé in meetings that can take up to several days. The community decides who should be the teachers, who should be the director, how to organize the school budget, where the school should be built, what kind of calendar the school should have, and virtually every other issue related to the school. An important example of the founders' respect for the indigenous people's wishes is that, as mentioned above, the curriculum has from the onset been designed by focusing on the Apyãwa Tapirapé culture and lifestyle. To include Apyãwa Tapirapé community activities - with the assumption that these are also part of the students' education - the curriculum was originally conceived to be quite flexible so as to allow students to spend more time with their families. In the beginning, for example, classes were not held every day. Although this seemed to be the best way to respect, promote, and maintain indigenous life in the 1980s, the Apyãwa Tapirapé community - pressured by the policies and negative evaluations of the surrounding non-indigenous society - asked the founders of the school to implement a strict, daily schedule. After a deep discussion within the community (Eunice Dias de Paula and Little Sisters of 
Jesus, 1999, p. c.), the school changed its schedule, and since then classes have been held every day and at specific hours, as can be seen in the non-indigenous schools.

Although Apyãwa Tapirapé bilingual education could be considered very successful, since the community has been in charge of the school and the students have demonstrated competence in both the indigenous language and Portuguese, many leaders and other people from the community are conscious of the changes the school has brought to the indigenous lifestyle. We will present their evaluation of these issues below, and discuss how schools can impact culture and language in indigenous communities. The analyzed data consist of excerpts (collected in August 2006) from recorded interviews with teachers and leaders representing all_of the Apyãwa Tapirapé villages. In these interviews, teachers and leaders discuss their school and explain their expectations and concerns about it. The interviewees are highly involved in community life and play important roles in their villages; their opinions largely reflect those of the Apyãwa Tapirapé community in general.

Interviewees Information

\begin{tabular}{|l|c|c|l|}
\hline Name & Age & Sex & Position in community \\
\hline Korira'i Tapirapé & 31 & M & Portuguese language teacher, Akara'ytawa village vice-chief \\
\hline Makato Tapirapé & 28 & F & Apyãwa Tapirapé language teacher \\
\hline Kamoriwa’i Tapirapé & 35 & M & Geography teacher and vice-chief of Tapi' itawa village \\
\hline Xywaeri Tapirapé & 55 & M & Apyãwa Tapirapé general chief \\
\hline Ieremy’i Tapirapé & 34 & M & Apyãwa Tapirapé language teacher \\
\hline Inamoreo Tapirapé & 35 & M & Geography teacher \\
\hline
\end{tabular}

\subsection{Positive Aspects of the Apyãwa Tapirapé Bilingual School}

This section presents the excerpts in which interviewees point out how the Apyãwa Tapirapé school program has been successful in helping the Apyãwa Tapirapé people. According to the interviewees, the school has contributed to the autonomy of the Apyãwa Tapirapé vis-à-vis Brazilian national culture. The Apyãwa Tapirapé people are now better able to fight for their rights without the assistance of non-indigenous agencies because they have become familiar with the non-indigenous language (Portuguese) and culture through their bilingual school. In addition, the school has helped them maintain their own language and culture through instruction in the Tapirapé language, as well as in native craftsmanship and agricultural practices. The first 
extract depicts the school as an important achievement for the Apyãwa Tapirapé people, since it has been helping them to learn the non-indigenous language and understand Brazilian culture as well as to maintain the indigenous culture and language:

(1) In my personal opinion, the Apyãwa Tapirapé school is a kind of conquest. Our school has helped us to know things that we didn't know before. It has taught non-indigenous knowledge and our culture too and made it stronger. (Korira'i Tapirapé, 08.19.06, male Portuguese language teacher, Akara'ytawa village vice-chief)

The speaker points out that the school allows the Apyãwa Tapirapé to "know things that we didn't know before" - such as Portuguese and the use of maps. In addition, a main goal of the school is to promote and maintain the indigenous language and culture, as the following three extracts illustrate:

(2) The most important thing is teaching in our language. If we are teaching in our language, we will not lose our culture (Makato Tapirapé, 08.21.06, female Tapirapé language teacher).

(3) Positive points of the school are related to knowing our own culture and language. School really helps us to revitalize our language and lifestyle, and to record our culture. In addition, school is teaching us how non-indigenous people behave. It has helped us in the fight for our lands, because we need to write documents in Portuguese for the Brazilian authorities (Kamoriwa’i Tapirapé, 08.22.06, male geography teacher and vice-chief of Tapi' itawa).

(4) School is important for us, because we are surrounded by nonindigenous people. So, the school is good for us: it teaches writing and reading, and documents our language by keeping a written record of it. Before the school, we didn't keep a record of the Tapirape language. We kept it only in our minds, in our memories. Nowadays, we are producing materials in our language. Also, school helps us dialogue with non-indigenous people. We need to understand them just as we need to write documents in Portuguese (Ieremy'i Tapirapé, 08.23.06, male Tapirapé language teacher).

Excerpts 2, 3, and 4 illustrate that knowledge about the non-indigenous culture and language is considered crucial in the fight for indigenous rights. Being surrounded by non-indigenous people was a determining factor in 
founding the school. In addition, as the interviewees argue, school created a new tool for Apyãwa Tapirapé people - a way to record the language for future generations, as pointed out in (4). On one hand, the interviewee claims that indigenous people have their own ways to save and protect their languages. They do not need school to do it. On the other hand, the non-indigenous presence forces indigenous people to search for extra ways to protect themselves. In this case, the extra way is the school which provides an additional mechanism to store the language and culture. Clearly the school is not an indigenous artifact. It was imposed by the violence of the contact with non-indigenous people and it has been appropriated by the Apyãwa Tapirapé people. This appropriation within the Apyãwa Tapirapé community entails giving meaning to and creating functions for that "foreign artifact".

The process of appropriation of the school is related to indigenous autonomy as well. As excerpt 5 below expresses, another goal of the school is to improve and promote indigenous independence in relation to nonindigenous people:

(5) The young people are being prepared by the school. In the future, we will not need non-indigenous advisors anymore. We are improving our autonomy. In this way school is a kind of tool (Inamoreo Tapirapé, 08.23.06, male geography teacher).

Autonomy - the right of a community to govern itself and to organize its own activities - can be fostered by the school, although the process may be a long one. Nevertheless, as the school is a non-indigenous invention, it must be shaped and directed by the indigenous people in order to ensure that it does indeed promote their autonomy. The Apyãwa Tapirapé people have been shaping their school from the beginning; however, full self-rule requires the training of young indigenous people to manage their school.

\subsection{Negative Aspects of the Apyãwa Tapirapé Bilingual School}

Although Apyãwa Tapirapé interviewees point out positive aspects of their school, most also recognize that the school has introduced profound changes in their lives, of which some are unanticipated and unwelcome. Some interviewees evaluate these changes as negative aspects of the school. One example is the amount of time that the school occupies in the students' daily lives, as described in excerpts 6 and 7: 
(6) Since the school's foundation, children have not been participating in traditional life. They do not go to the fields anymore, and they don't have time to spend with their families. Nowadays, parents encourage their kids only to go to school (Korira'i Tapirapé, cited above).

(7) Before the school, we used to go to the fields or to the river to fish and hunt with our children. Nowadays it is really difficult to do these things, because children start school when they are 7 years old, and this does not allow them to go out of the village with their parents. This is a negative aspect of school (Kamoriwa'i, cited above).

According to these interviewees, the bilingual school has reduced the traditional spaces in which young people can learn about Apyãwa Tapirapé culture. The students have less time to spend with their parents, because they are required to go to school every day. Some of them do not learn how to cultivate traditional crops, and they receive less instruction according to traditional, handson Apyãwa Tapirapé pedagogy, which is based on observation and repetition. When there was no school in the village, children used to learn in public spaces like the fields, the forest, the river beach, or the family home, but this now occurs less frequently. The interviewees emphasize that there is an indigenous education that it is not associated with schooling. The school is not able to teach many of those skills that are acquired in a hands-on setting; only the time spent with the extended family provides the opportunity for apprenticeship. This time with the family also allows for the enrichment of native language usage and learning. Although school has been appropriated by the Apyãwa Tapirapé people, many Apyãwa Tapirapé feel that it is still a non-indigenous creation that should not usurp the traditional indigenous learning spaces.

The following passage emphasizes the ideas presented in excerpt 6 and 7 above and adds that the school is stealing time not only from the children, but also from the adults who work in the school. According to this interviewee, teachers are spending a great deal of time in school and do not have time to spend with their families or to cultivate traditional crops - implying a poor use of Apyãwa Tapirapé land:

(8) The school works to teach non-indigenous culture, but not our culture. The school doesn't work well in this case: we have our land and nobody uses it. Teachers don't have time to cultivate the fields. Non-indigenous people are bullying us, saying we are lazy people. In addition, school doesn't allow children to fish or spend time with their parents. As far as non-indigenous culture is concerned, school is good; 
we are learning about it. But our culture, it will be destroyed step-bystep, slowly (Xywaeri Tapirapé, 08.22.06, Tapirapé chief)

This interviewee points out a further impact of the school, relating to the non-indigenous evaluation of the way the Apyãwa Tapirapé are using their land. It brings up a conflict experienced by many indigenous communities. On one hand, they are obliged to adopt a school - a non-indigenous artifact - and if they do not, they are labeled "uncivilized". On the other hand, if the school occupies too much of the time needed for traditional activities, they are criticized for being lazy. This interviewee is also concerned about the Apyãwa Tapirapé culture and believes that it will be slowly lost. A related issue involves the maintenance of the native language, as illustrated by excerpt 9:

(9) We have been mixing our language with Portuguese. We didn't use to do this but, nowadays, there are a lot of words that we don't have in our language. Children are hearing these words in Portuguese, in school and other places, and using them in the Tapirapé language (Ieremy'i Tapirapé, cited above).

Despite the emphasis on teaching in Tapirapé, Portuguese has gained prestige in the community. There has been an increase in code-switching. Although this has not yet affected the vitality of the indigenous language, interviewees argue that it threatens their language, and they have identified the school as the culprit of this phenomenon. The interviewees are aware that their language is in conflict with a majority language and that school has an important role in controlling or not controlling the code-switching that is taking place.

The negative evaluations considered here focus on the changes in the traditional lifestyle that have been brought about by bilingual schooling. Although the Apyãwa Tapirapé leaders point out these problems, this does not imply that they do not want a school in the village. Their concerns simply illustrate the conflicts inherent in the school as a place where two different worlds are in contact - the indigenous and the non-indigenous.

\section{Apyãwa Tapirapé evaluation as indication of multiple identities and representations}

The evaluations cited above reveal the "antagonistic representations" (WOODWARD, 2000) with which the Apyãwa Tapirapé people view their school and its effects on the community. The positive and negative points of 
view suggest that the process of constructing bilingual schooling is complex and multifaceted. As a non-indigenous institution, a school must be appropriated by the indigenous people it serves, as well as re-constructed continuously, in order to be truly effective; however, conflicting priorities and interests are an unavoidable part of the process. The positive and negative evaluations of the interviewees come both from the process of constructing or shaping the school itself as well as from the construction of its meaning within the community. Meaning is constructed from a set of representations (WOODWARD, 2000) and can itself be considered a representation, but these representations are not homogeneous within the community or even within individuals, as illustrated by the positive and negative evaluations of the Apyãwa Tapirapé school presented here.

These conflicting evaluations can be understood to reflect conflicting and antagonistic aspects of Apyãwa Tapirapé identity. On one hand, those interviewed are in favor of the Apyãwa Tapirapé school, as it helps them preserve their native culture and language and provides a way of learning the non-indigenous language, understanding both Brazilian and world cultures, while at the same time assisting them in their fight for their rights. On the other hand, they are against the school, because it threatens their culture by introducing Portuguese and by taking time away from the family's education of their children. These different points of view do not necessarily mean that the Apyãwa Tapirapé people are confused about their school, but rather indicates the different facets of their identity as a people. This is best understood if we bear in mind that identities are fluid and are constructed in contrast and in opposition to another individual or group (HALL, 1992); for the Apyãwa Tapirapé, this opposing group is that of non-indigenous people. When thinking and talking about the school, those interviewed are dealing with an artifact invented by the non-indigenous world and imposed on the Apyãwa Tapirapé but which has been appropriated by them, thus generating conflicting positions on the same topic.

The bilingual school contributes to the construction of these antagonistic and conflicting identities because it is a hybrid space (BHABHA, 2003) where two different cultures are in contact. Spaces for indigenous and non-indigenous culture are constantly negotiated; therefore, conflict and antagonism are a part of this hybrid and fluid scenario. Antagonism and conflict cannot be evaluated as either correct or incorrect, but rather as a natural part of the hybrid model as well as a reflection of different aspects of the 
situation. There is, thus, no unique or fixed solution for the problems presented by those interviewed here. However, hybridism and fluidity also imply room for flexibility and change, which, as we have seen here, are crucial ingredients for the success of a bilingual school like that of the Apyãwa Tapirapé. Hybridism and fluidity suggest that not every decision is set in stone, and can be duly changed to best suit the needs and interests of the community.

\section{Implications and recommendations}

However, while hybridism and fluidity may cause conflict, they also permit mobility and flexibility. These are essential features of an indigenous school, allowing for a continuous shaping of the school, particularly by the indigenous people themselves. The problems raised by the Apyãwa Tapirapé interviewees can in principle be solved if the community recognizes that its decisions are not set in stone and can be modified. For example, they have identified the school as the culprit of this phenomenon. The strict schedule of the school - which was chosen by themselves but is causing problems - can be changed if the community decides to do so, allowing more time for young people to spend with their families.

The most relevant proposal might be to rethink the political pedagogical project of the school in order to meet the needs of the Apyãwa Tapirapé tribe and to ensure the flexibility of the curriculum to be used for the community education, so that it is integrated with the traditional systems. This requires the Apyãwa Tapirapé tribe to reassess all stages of the educational process and review their positions, because, in many instances, due to the pressure from the majority of society, they have restructured the school. All changes resulting from these requirements have buried the school and have denied the Apyãwa Tapirapé of their creativity. This result does not necessarily mean that the Apyãwa Tapirapé are "guilty" of the problems that the school has generated. However, they do seem to be more united against the non-indigenous world, on the one hand, and more knowledgeable of the process of schooling, on the other, given that they are reflecting on the issue and can therefore implement the necessary changes if they so desire.

Added to this is the fact that, in the current Brazilian context, an everincreasing number of experiences of indigenous schools with political pedagogical projects can be observed. These schools are closer to the traditional systems of indigenous life and more respectful of the educational processes of each peoples, which the Apyãwa Tapirapé should take into consideration to 
better elucidate the discussion on this issue. Therefore, the community can now assess and better position themselves in relation to the problems they believe must be resolved more urgently. This reflection will make it possible, for example, to make the decision to cut school days, to set the time to go to school in accordance with the time to go to work in the fields, and not to accept all the demands imposed by the state, i.e., to develop and implement a new political pedagogical project in which the traditional systems of the transmission of education and knowledge on the part of the Apyãwa Tapirapé are considered. In this sense, it will be necessary to revisit and rethink the school so that it can work in conjunction with the indigenous educational systems, allocating specific times and spaces for each culture.

In conclusion, the hybridity and fluidity of the indigenous school can facilitate the ongoing evaluation and reconstruction of the educational program, in a continuous process of shaping it to meet the needs of the communities.

\section{Conclusion}

In the context of the struggle to preserve endangered languages, the Apyãwa Tapirapé case provides an important illustration of a successful bilingual education program. However, as this study shows, even a successful school is likely to bring complications for the community. On one hand, the access to Portuguese and the familiarity with the non-indigenous culture, facilitated by the school, have contributed to the ability of the Apyãwa Tapirapé people to fight for their rights and to retain their autonomy in relation to Brazilian national society. In addition, the school has helped them maintain their own language and culture through instruction in the Tapirapé language, as well as through the teaching of traditional skills and agricultural practices. On the other hand, the school has occupied traditional spaces of apprenticeship by reducing the time in which young people can acquire cultural and linguistic skills in a traditional manner, through interaction with their extended families. Furthermore, the school has contributed to an increase in code-switching by teaching the Portuguese language, which some community members feel is a threat to the maintenance of Tapirapé. All these issues indicate that bilingual schooling may initiate profound social changes while at the same time meeting certain needs from peoples such as the Apyãwa Tapirapé. The anguish and conflict that these changes may cause are linked to the hybrid, fluid nature of the bilingual school as a space where two different worlds come into contact. 


\section{References}

BHABHA, H. The location of culture. London; New York: Routledge, 2003.

CAVALCANTI, M. C. Entre escolas da floresta e escolas da cidade: olhares sobre alguns contextos escolares indígenas de formação de professores. Trabalhos em Linguistica Aplicada, n. 36, p. 101-119, July./Dec. 2000.

CRYSTAL, D. Why we should care? In: . (Ed.). Language Death. Cambridge University Press: 2000. p. 27-77.

D'ANGELIS, W. A escola entre os Kaingang. Available at http://www.portalkaingang. org/index_educ_I_II_cont_1.htm\#. Retrieved on February 3, 2013.

DIAS DE PAULA, E. Os Tapirapé e a escrita: indícios de uma relação singular, (Masters Thesis in Linguistics). Faculdade de Letras: Universidade Federal de Goiás, 2001.

ERICKSON, Frederick. Metodos cualitativos de investigación sobre la ensenanza. In: WITTROCK, M. (Org.). La investigacion de la ensenanza. Barcelona: Ediciones Paidos, 1989. p. 195-301.

ELY, M.; ANZUL, M.; FRIEDMAN, T; GARNER, D.; STEINMETZ, A. M. Doing qualitative research: circles within circles. London: The Falmer Press, 1991. EMERSON, M.; FRETZ, R.; SHAW, L. Writing ethnographic fieldnotes. Chicago \& London: University of Chicago Press, 1995.

FREIRE, P. Educação como prática de liberdade. São Paulo: Paz e Terra, 1967.

FREIRE, P. Pedagogia do oprimido. São Paulo: Paz e Terra, 1968.

HALE, K. On endangered languages and the safeguarding of diversity. Language, v. 68 , n. 1 , p. 1-3, 1992.

HALL, S. A identidade cultural na pós-modernidade. Rio de Janeiro: DP\&A, 1992.

HINTON, L. Language Revitalization: An Overview. In: HINTON, L. The Green Book of Language Revitalization in Practice. San Diego: Academic Press, 2001. p. 3-18.

INSTITUTO SÓCIO-AMBIENTAL. Formatura da 2a turma da Escola Tuyuka consolida conquistas da educação escolar indígena, Available at http:// www.socioambiental.org/nsa/detalhe?id=2459. Retrieved on February 1 ${ }^{\text {st }}, 2008$. JULCA-GUERRERO, F. Uso de las lenguas quechua y castellano en procesos de educacion bilingue intercultural. (Masters Thesis in Bilingual Intercultural Education). PROEIB Andes-Universidad Mayor de San Simon, 2000.

KRAUSS, M. The world's languages in crisis. Language, v. 68, n. 1, p. 4-10, 1992. MASON, Jeniffer. Qualitative Researching. London: SAGE Publications, 1997. 
NETTLE, D.; ROMAINE, S. A world of diversity. In: (Ed.) Vanishing voices: The Extinction of the World's Languages. Oxford: Oxford University Press, 2000. p.26-49.

SILVA, T. F. Novas terras, novos céus: a educação escolar entre os Xavante de Sangradouro. Revista de Educação Pública, UFMT, v. 1, n. 12: July/Dec. 1998. Available at: http://www.ufmt.br/revista/arquivo/rev12/novas_terras.html. Retrieved on February 2, 2008.

WATAHOMIGIE, L.; YAMAMOTO, A. Local reactions to perceived language decline. Language, v. 68, n. 1, p. 10-17, 1992.

WOODWARD, K. Identidade e diferença: uma introdução teórica e conceitual. In: SILVA, T. T. (Org.). Identidade e diferença: a perspectiva dos estudos culturais. Rio de Janeiro: Vozes, 2000. p. 7-72.

Data de submissão: 10/09/2013. Data de aprovação: 11/02/2014. 